\title{
Poor People's Perceptions of Government Support for Entrepreneurship and Small Business Promotion in a Developing Country
}

\author{
Natanya Meyer \\ North-West University, Vaal Triangle Campus, South Africa \\ natanya.meyer@nwu.ac.za
}

\begin{abstract}
Unemployment is a global concern; therefore many developing countries focus on entrepreneurship development and small business promotion as a possible solution. Entrepreneurs are regarded as drivers of the economy as they not only provide income for themselves but also create job opportunities for other people. The South African Government focuses on job creation as a priority, involving many strategies and policies. However, many marginalised and impoverished people still do not benefit from these policies. The central purpose of this article is to analyse poor people's perceptions of the role of government in creating jobs and assistance in providing entrepreneurial skills training and support. A socioeconomic household survey, consisting of approximately 3200 households, was conducted within various areas in the Metsimaholo, Moqhaka, Ngwathe and Mafube Local Municipalities, all located in the rural Northern Free State region in South Africa. Results of the survey show that $68.3 \%$ of participants feel that government is not doing enough to create jobs while a total of $49.1 \%$ indicated that government could assist in job creation by providing entrepreneurial skills training. A total of 56.2\% indicated that they would like to open a small business. Improved government support and initiatives could lead to many poor households generating their own income through entrepreneurial activities.
\end{abstract}

Keywords: Entrepreneurship, Government support, rural townships, small business development, South Africa

\section{Introduction}

Over the years, various constraints that affect many developing countries, including South Africa, have been identified. Of the main problems, the three that are linked are unemployment, leading to poverty, which ultimately causes inequality in communities and countries (Phillips, Moos \& Nieman, 2014; The National Planning Commission, 2012). In trying to resolve these issues and as a result of failure to absorb job seekers in the public and private sectors, many South African policies are aimed at supporting development of small businesses and entrepreneurship. A considerable number of researchers and policy makers regard entrepreneurship as a link to sustained and increased economic development and growth. Entrepreneurship and small business development is not only a priority in developing countries but also in developed countries because it is perceived as a driver of accelerated economic growth. Developing countries need entrepreneurial enabling environments and lenient regulations to stimulate new business development, thereby ultimately creating new employment opportunities (Kroon, 2002; Botha, Nieman \& van Vuuren, 2007; Sivvam, 2012; Ambrish, 2014; Phillips, Moos \& Nieman, 2014). The South African Government has devoted vast amounts of resources in supporting entrepreneurs and small businesses since 1994. Despite this, South Africa was rated $35^{\text {th }}$ out of the 54 countries participating in the Global Entrepreneurship Monitor (GEM) in 2009 and dropped to 53 $3^{\text {rd }}$ out of 70 countries in the 2014 report (Herrington, Kew \& Kew, 2009; Herrington, Kew \& Kew, 2015). In addition, South Africa's reported early-stage entrepreneurial activity (TEA) rate is also performing poorly, well below the average. Government development efforts should include financial and non-financial support, especially to previously disadvantaged groups and marginal communities. The aim of this article is therefore to analyse poor people's perceptions of the role of government in creating jobs and assistance with entrepreneurial skills training and support in their communities. 


\section{Literature Review}

No consensus exists on how or when government should intervene in the economy or to what extent any interventions should be implemented. But one certainty is that developing countries and struggling communities should be assisted with sustainable methods to support themselves (Koven \& Lyons, 2003). Entrepreneurship and small business development should be considered one of the tools or methods within a Local Economic Development (LED) strategy (Meyer, 2013; Meyer, 2014) to achieve this. Never before has entrepreneurship been more important than it is currently. Entrepreneurs are fundamentally creators of new employment and wealth. In addition, they also address and often resolve challenges which societies face across the globe. Entrepreneurs are innovative and creative and they come in all shapes and sizes (WEF, 2011). As Rania Al Abdullah stated at the Global Education Initiative private meeting in Davos in 2007, "society faces a strong need to encourage people to practice believing the unbelievable, using imagination and courage and tapping into the inner entrepreneur". She added that with the right skills and mind-set entrepreneurs can be created even outside of the formal education system (WEF, 2007).The Department of Rural Development and Land Reform (2010) concurs, indicating that support for local entrepreneurship and leadership is needed in rural areas to strengthen linkages with the main economic hubs, improve income levels and address the poverty and quality of life in such areas. The development potential of rural towns is determined by several factors: diversity of local culture, geography and terrain, complexity and level of the local economic systems, access to technology, quality of local leaders and level of entrepreneurship (Meyer, 2013). Many impoverished people living in rural areas lack the necessary resources in order to successfully start and manage a small business. These resources include, but are not limited to, education, skills, training, access to credit and lack of basic infrastructure (Field, Jayachandran \& Pande, 2010). In addition to this, indigent rural women are even more disadvantaged by other barriers and challenges, such as lack of business management skills, inter-role conflict, high risk averseness, lack of female role models, inequality and gender bias, lack of confidence as well as the pressure of child care (Kock, 2008; Lebakeng, 2008).

Definitions: Many different definitions have been developed over the years to explain the term "entrepreneurship". In an earlier definition from the early 1930's (cited in De Bruin, Brush \& Welter, 2006) "entrepreneurs" are described as those who "create new combinations, new markets, and product or distribution systems". More recently, entrepreneurs were described as people who added value and wealth by creating new processes and developing new ideas, assembling resources and taking action to make things happen (Ambrish, 2014). Some of the traits frequently associated with entrepreneurs include being risk takers, being innovative, exploiting opportunities, being success driven, thinking outside of the box as well as being creative and optimistic. Various definitions also exist for the term "small business" and are linked to factors such as size, the country the enterprise is situated in, annual turnover, number of employees and even the industry or sector within which the business falls. But consensus exists that it is an independently or privately owned and operated business forming part of a specific economic sector. Small businesses are often referred as suppliers of specific needs within a community (SBA, 2015) and are considered important contributors to LED. The South African Revenue Service even provides a zero tax rate for small businesses registered as a Small Business Corporation (SBC) and complying with certain criteria up to a taxable annual income of R73 650(approximately $\$ 5877.80$ at R12.53 per \$) in order to assist with growth potential (SARS, 2015). No clear or generally acceptable definition of "rural" exists, but this could be classified as an area where human settlements and infrastructure occupy only small portions of the landscape and consist of up to 10000 people (Gauteng Department of Agriculture and Rural Development, 2011)."Poverty" is defined as "a situation where an individual lacks command over commodities that are deemed essential to realise a reasonable standard of living" (World Bank, 2001). Poverty can further be described as an absence of income which results in inadequate health, housing, education and access to resources and basic services (Meyer, 2013).

The role of government in economic development: Meyer (2013) opines that the role of the government in development includes various aspects. These include, but are not limited to, ensuring a stable political environment, policy implementation, good governance, support and assistance with creation of employment, as well as provision of social grants and support to poor communities. Vidovic (2014) adds to this perspective by indicating that the state or government performs three main functions: distribution, stabilisation and allocation. A key role of government in development is creating an enabling environment for the local 
communities and private sector to flourish and be successful (Phillips, Moos \& Nieman, 2014). This can only be achieved by strong leadership and coordination. Another important contributor to development is skills training; government could assist local entrepreneurs to start small businesses by undertaking research in product development. As the local government is the sphere of government nearest to rural communities, it should play the most involved role including facilitation, coordination, stimulator, enabler and even developer. In addition to this, further assistance should be provided in the form of one-stop-information centres, marketing the region, providing incubators, job centres and skills development (Meyer, 2013). In an attempt to develop entrepreneurship, the South African government entrusted the Department of Trade and Industry with synchronising important features of implementation filtering from government support strategies (Phillips, Moos \& Nieman, 2014). According to Rogerson (2004) the South African government has done a very good job in creating supporting policies and has put in vast amounts of resources to support small business but the implementation of these policies are questionable.

Support to small businesses and entrepreneurs: Since 1994, as mentioned the South African government has invested immense resources in order to assist entrepreneurs and small businesses, especially in previously disadvantaged and marginal communities. Some of these entrepreneurial initiatives to create an enabling environment for new entrepreneurs include the Small Enterprise Development Agency (SEDA), the Gauteng Enterprise Propeller (GEP), the Small Enterprise Finance Agency (SEFA), and the National Empowerment Fund (NEF) (SEDA, 2015; GEP, 2015; SEFA, 2015; NEF, 2015). Contrary to this, many obstacles also exist that hinder an easy start up for entrepreneurs and small business success. These include rigorous labour and tax laws and unnecessary red tape when registering a new business. As a result of the limited success of government programmes many private businesses and other groups have also started programmes to support entrepreneurs.

\section{Methodology}

Sample: The sample for this study consisted of rural poor people residing in various areas in the Metsimaholo Local Municipality, Moqhaka Local Municipality, Ngwathe Local Municipality and Mafube Local Municipality, all located in the northern Free State Province, South Africa. Criteria for selecting the respondents were that they had to be residing in a rural and impoverished area or township. The following townships were selected for the household survey conducted during 2013:Moakeng (Kroonstad), Rammulotsi (Viljoenskroon), and Matlwangtlwang (Steynsrus),all situated in the Moqhaka local municipal area; Zamdela (Sasolburg), Refengkgotso (Deneysville), and Metsimaholo (Oranjeville),situated in the Metsimaholo municipal area; Namahadi (Frankfort), Qalabotjha (Villiers), Ntswanatsati (Cornelia), and Mafahlaneng (Tweeling),situated in the Mafube local municipal area. Towns situated in the Ngwathe municipal area include Tumahole (Parys), Phiritona (Heilbron), Makwallo (Vredefort), Ngwathe (Edenville), and Kwawatsi (Koppies).

Sampling method: The data was collected per household using a community survey method. Layout plans of all the areas surveyed were collected from the various municipalities in order to determine the sample stratification regarding the geographical distribution and concentration of households in the area. The questionnaire was designed with an electronic answer sheet for ease of capturing.

Research instrument and method: A questionnaire was designed after in-depth literature reviews and a comparison of similar studies' questionnaires. This comprised predominantly closed-ended, multiple-choice questions in order to simplify the data analysis process. The questionnaire was pre-tested, after which the contents were finalised. Field workers were trained to complete the survey with the respondents from the various households, and a total of 3208 households were interviewed. Each member in the household was interviewed to determine their employment status, income, skills, preferences to employment etc. The survey data was analysed by means of SPSS. The focus was placed on levels of poverty, skills and perceptions of local government in rural communities. However, for this article only the data from questions pertaining to respondent's perception of government support towards small business and entrepreneurial assistance was used. 


\section{Results and Discussion}

During the data collection process 3208 questionnaires were collected from various communities and townships in the northern Free State area. This province is also known as the central province of South Africa and covers approximately $10.6 \%$ of the total area of the country. The Free State consists of five district municipalities; this study is focused on one of these: the Fezile Dabi District Municipality. This municipality consists of four local municipalities: the Ngwathe, Moqhaka, Metsimaholo and Mafube Local Municipalities. It is considered an important agricultural and industrial area, containing major environmental features such as the Vaal River, the Vredefort Dome and the Vaal Dam (Meyer, 2013). Table 1 summarises some key components of general information regarding the area.

Table 1: Summary of general information

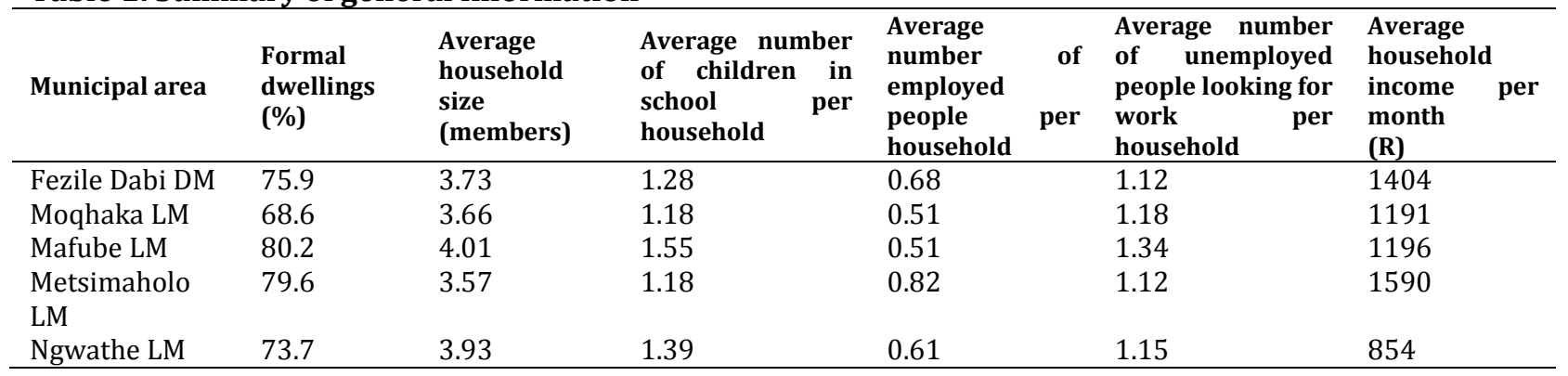

Source: Meyer, 2013

From Table 1, it is evident that the areas under discussion are considered poor with an average income of only R1 404 (approximately $\$ 112.1$ ) per household per month. If divided by the average household size, this amount equates to a mere R376.40 (approximately \$30.04) per person per month which is below the poverty line of $\$ 1.25$ per day. Many different calculations have been performed to determine the level of poverty and minimum amounts deemed adequate to live a quality life, ranging from $\$ 1.00$ to $\$ 2.50$ per person per day (Ravallion, 2010), but the most common rate used as per the World Bank is set at $\$ 1.25$ per person per day (Meyer, 2013). At the current rand/dollar conversion rate (R12.53 per $\$ 1$ as per date of completing this article), $\$ 1.25$ equates to approximately R15.66 per day. Multiply this by an average of 30 days and the poverty line can be set at approximately R469.80 per person per month. From the data it is also evident that more people per household are unemployed and seeking employment than those who are actually working and generating an income. In addition to Table 1, the average number of youths (15-24 years old) in the total region who is not working per household was calculated at 0.55 . With the current youth unemployment rate at above 50 percent in South Africa, this figure adds to the globally growing concern over youth unemployment issues (StatsSA, 2015). The survey further found that the skills of the unemployed people who participated were predominantly in the farming/gardening and catering/cooking industries, followed by the building/construction and retail/selling sectors. Table 2 indicates the level of entrepreneurial intent regarding whether or not respondents want to open a small business.

Table 2: Entrepreneurial intent per municipal area

\begin{tabular}{lllll}
\hline Municipal area & $\mathbf{N}$ & $\begin{array}{l}\text { Respondents who } \\
\text { would like to open } \\
\text { small business (\%) }\end{array}$ & $\begin{array}{l}\text { Respondents who do } \\
\text { not want to start } \\
\text { small business (\%) }\end{array}$ & $\begin{array}{l}\text { Respondents who } \\
\text { are uncertain (\%) }\end{array}$ \\
\hline Fezile Dabi DM & 3208 & 56.2 & 34.2 & 9.6 \\
Moqhaka LM & 530 & 57.8 & 35.8 & 6.4 \\
Mafube LM & 270 & 51.7 & 45.2 & 3.1 \\
Metsimaholo LM & 1422 & 45.7 & 39.1 & 15.2 \\
Ngwathe LM & 986 & 72.8 & 22.4 & 4.8 \\
\hline
\end{tabular}

Source: Own Compilation

Table 2 clearly indicates that respondents have entrepreneurial intent as 56.2 percent of all respondents replied that they would like to start a small business in the region. Metsimaholo Local Municipality (LM) 
recorded the lowest intent at 45.7 percent and Ngwathe LM the highest with 72.8 percent. An effort should be made to involve these respondents in entrepreneurial development programmes and provide them with the necessary assistance to possibly start a small business. In addition to asking respondents if they would like to start a business, they were asked what type of business they would like to start. The responses were as follows: 12.5 percent were interested in opening a farming or gardening business; 37 percent a retail/selling business; within the catering and cooking sector, 20 percent; while 9.6 percent were interested in a sewing or clothing business; 13.2 percent in the building, construction, electrician or plumbing industries, with 5.3 percent and 2.4 percent in the computing and steelwork/welding sectors respectively. Table 3 reflects the opinions of respondents regarding the role the government is playing in creation of new job opportunities. Respondents were asked if they thought that government is doing enough to create new jobs.

Table 3: Government's role in creating new employment opportunities

\begin{tabular}{|c|c|c|c|c|}
\hline Municipal Area & $\mathbf{N}$ & $\begin{array}{l}\text { Respondents who } \\
\text { think that } \\
\text { government is not } \\
\text { doing enough (\%) }\end{array}$ & 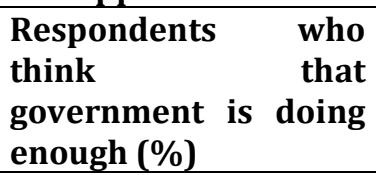 & $\begin{array}{l}\text { Respondents who } \\
\text { are uncertain (\%) }\end{array}$ \\
\hline Fezile Dabi DM & 3208 & 68.3 & 18.7 & 13 \\
\hline Moqhaka LM & 530 & 57.1 & 29.8 & 13.1 \\
\hline Mafube LM & 270 & 68.1 & 19.8 & 12.1 \\
\hline Metsimaholo LM & 1422 & 72.4 & 16.2 & 11.4 \\
\hline Ngwathe LM & 986 & 68.7 & 15.8 & 15.5 \\
\hline
\end{tabular}

Source: Own Compilation

A total of 68.3 percent of respondents from households in the region were of the opinion that government is not doing enough to assist in the creation of jobs and new employment opportunities while 18.7 percent feel satisfied with the role government is playing. The Metsimaholo LM households are the least satisfied with the local government's role in job creation efforts while Moqhaka LM are the most satisfied, but still generally unsatisfied. Respondents were further asked how government could assist in the job creation process; a summary of the results is listed in Table 4.

Table 4: Government's assistance and support required

\begin{tabular}{llllllll}
\hline $\begin{array}{l}\text { Municipal } \\
\text { area }\end{array}$ & $\mathbf{N}$ & $\begin{array}{l}\text { Skills } \\
\text { training } \\
(\%)\end{array}$ & $\begin{array}{l}\text { Public works } \\
\text { projects (\%) }\end{array}$ & $\begin{array}{l}\text { Provide } \\
\text { facilities } \\
\text { (\%) }\end{array}$ & $\begin{array}{l}\text { Provide } \\
\text { land } \\
\text { (\%) }\end{array}$ & $\begin{array}{l}\text { Assist with } \\
\text { finance (\%) }\end{array}$ & $\begin{array}{l}\text { Support } \\
\text { co-ops } \\
\text { (\%) }\end{array}$ \\
\hline Fezile Dabi DM & 3208 & 49.1 & 33.6 & 5.0 & 4.0 & 3.1 & 3.8 \\
Moqhaka LM & 530 & 58.5 & 27.2 & 4.0 & 2.5 & 1.5 & 4.4 \\
Mafube LM & 270 & 58.5 & 28.5 & 4.6 & 2.3 & 2.3 & 1.9 \\
Metsimaholo & 1422 & 44.5 & 41.2 & 5.7 & 4.1 & 2.4 & 1.5 \\
LM & & 47.5 & 28.2 & 4.5 & 5.2 & 5.2 & 7.2 \\
Ngwathe LM & 986 & & & & & \\
\hline
\end{tabular}

Source: Own Compilation

From Table 4, it is evident that all the areas under discussion have a strong need for skills training because all reported a rate of above 40 percent, with Moqhaka LM and Mafube LM being the highest at 58.5 percent. The second most important resource requested by respondents was the development of new public works projects, in other words projects financed and constructed by government in order to provide infrastructure for various purposes to the community (APWA, 2015). These projects generally create large volumes of work opportunities which are not sustainable over a long period as they are normally contract based. In a study conducted by Thawala (2008) it was found that South African public works programmes were in many cases not properly implemented and managed. These programmes do create employment and entrepreneurial development, but at a very high cost to the taxpayers. Some problems arising from South African public works programmes included lack of clear objectives and long-term vision; they are unsystematic and fragmented; there are inappropriate administration processes and corruption; there is a lack of government commitment as well as inadequate project maintenance (during and after); lack of training that should result in long-term development; mostly politically driven with very little long-term sustainable employment being 
created. Respondents further indicated that they require facilities, land, finance and support for co-ops. What was surprising was that respondents from all of the areas reported a very low need for finance. A possible explanation for this could be that respondents feel that they first need to acquire skills so that using money provided for starting a business would be wisely spent.

\section{Conclusion and Recommendations}

It is evident from the study that three of the main problems in the South African society: poverty, unemployment and inequality, are prominent in the study region. Households that participated in the study felt let down by government as they believe that government is not assisting enough in the creation of employment opportunities. In general, the households have fewer people who are in employment than they have who are actively seeking employment. The households are also very poor and in general earn less than the $\$ 1.25$ per day rate deemed adequate to live a quality life. A new poverty line of $\$ 2$ per day is used in many instances and this rate reveals the study group as even more impoverished than against the previous measure. More than half of the households interviewed in the region would like to start a business and require assistance predominantly in skills training from the government. One of the main challenges to rural development is to disrupt the "vicious cycle of poverty". This could to a certain extent be achieved by providing poor communities the tools to help themselves. Entrepreneurship development should definitely be considered as one of these tools. Other important factors to consider in rural development are improved community development, improved leadership, more active citizenship and rising living standards through economic opportunities. This can partly be achieved through entrepreneurship. Some possible recommendations for improving job creation, entrepreneurship and small business development through government initiatives in rural areas include:

- Economic development: focussing on projects in the region that may lead to economic development and growth in employment opportunities

- Creation of labour intensive projects: economic sectors that have the potential to create labour intensive jobs should be supported

- Creation of an enabling environment for local small businesses: this includes functions such as provision of land, creation of development zones, provision of services and infrastructure, access to finance, tax policies and incentives

- Local community involvement: if community members are involved to a certain extent in decision making processes such as planning and implementation, it could create a sense of belonging and social cohesion

- Skills training and development: local people should be invited to special skills training workshops provided for them in their area

- Support of local businesses: government should support local business initiatives by granting small tenders such as infrastructure maintenance, grass cutting and other similar projects to entrepreneurs in the specific area

- Clustering of businesses: clustering of similar, interconnected and competitive industries could lead to enhanced competition and new innovation

- Providing incubators and mentorship: building business incubators in the various areas and providing mentorship to entrepreneurs and small business owners could accelerate growth potential

\section{References}

Ambrish, D. R. (2014). Entrepreneurship development: An approach to economic empowerment of women. International Journal of Multidisciplinary Approach and Studies, 1(6), 224-232.

APWA (American Public Works Association). Discover public works. Retrieved fromhttp://www.apwa.net/discover.

Botha, M., Nieman, G. \& van Vuuren, J. (2007). Measuring the effectiveness of the Women Entrepreneurship Programme on potential, start-up and established women entrepreneurs in South Africa. South African Journal of Economic and Management Sciences, 10(2), 163-183.

De Bruin, A., Brush, C. G. \& Welter, F. (2006). Introduction to the special issue: Towards building cumulative knowledge on women's entrepreneurship. Entrepreneurship Theory and Practice, (2), 585-593. 
Department of Rural Development and Land Reform (DRDLR). (2010). A study on the revitalization of rural towns and regions in South Africa. Department of Rural Development and Land Reform. Pretoria: Government Printers.

Field, E., Jayachandran, S. \& Pande, R. (2010). Do traditional institutions constrain female entrepreneurship? A field experiment on business training in India. American Economic Review, Papers and Proceedings, $100,125-129$.

Gauteng Department of Agriculture and Rural Development (GDARD). (2011). Gauteng comprehensive rural development strategy. Information brochure. Branch: Rural development. Johannesburg.

GEP (Gauteng Enterprise Propeller). (2015). Home Page. Retrieved fromhttp://www.gep.co.za

Herrington, M., Kew, J. \& Kew, P. (2009). Tracking entrepreneurship in South Africa: a GEM perspective. University of Cape Town, Cape Town South Africa.

Herrington, M., Kew, J. \& Kew, P. (2015). 2014 GEM South Africa Report: South Africa: The crossroads - a goldmine or a time bomb? University of Cape Town, Cape Town South Africa.

Kock, A. (2008). A framework for the development of entrepreneurship in the Ekurhuleni district. Potchefstroom: North-West University. (Unpublished MBA mini-dissertation.)

Koven, S. G. \& Lyons, T. S. (2003). Economic development: strategies for state and local practice. Washington DC: ICMS.

Kroon, J. (2002). 'n Strategie vir entrepreneurskapsontwikkeling in Suid-Afrika. Tydskrif vir Geesteswetenskappe, 42(3), 215-223.

Lebakeng, M. A. (2008). An exploration of women entrepreneurship in Lesotho. Potchefstroom: North-West University. (Unpublished MBA mini-dissertation.)

Meyer, D. F. (2013). An exploration of revitalization strategies for rural areas: the case of the northern Free State. Potchefstroom: North-West University. (PhD Thesis.)

Meyer, N. (2014). Creating an entrepreneurial culture among students through entrepreneurship development programmes (EDP). Mediterranean Journal of Social Sciences, 5(13), 281-288.

NEF (National Empowerment Fund). (2015). About the NEF. Retrieved fromhttp://www.nefcorp.co.za/ About brtheNEF/StrategicPositioning.aspx

Phillips, M., Moos, M. \& Nieman, G. (2014). The impact of government support initiatives on the growth of female businesses in Tshwane South Africa. Mediterranean Journal of Social Sciences, 5(15), 85-92.

Ravallion, M. (2010). World Bank's \$1.25/day poverty measure: countering the latest criticisms. Retrieved fromhttp://econ.worldbank.org/WBSITE/EXTERNAL/ EXTDEC/ EXTRESEARCH/ 0,,content MDK:22510787 pagePK:64165401 piPK:64165026 theSitePK:469382,00.html

Rogerson, C. M. (2004). The impact of the South African government's SMME programmes: a ten year review (1994-2003). Development and Southern Africa, 21(5), 765-874.

SARS (South African Revenue Service). (2015). Small business. Retrieved from http://www.sars.gov.za/ Client Segments/Businesses/Small Businesses/Pages/default.aspx.

SBA (Small Business Association). (2015). Small business size standards. Retrieved from https://www.sba.gov/category/navigation-structure/contracting/contracting-officials/smallbusiness-size-standards.

SEDA (Small Business Development Agency). (2015). Welcome to the Small Enterprise Development Agency. Retrieved fromhttp://www.seda.org.za/Pages/Home.aspx

SEFA (Small Enterprise Finance Agency). (2015). Home Page. Retrieved fromhttp://www.sefa.org.za

Sivvam, M. (2012). Women entrepreneurship: An Indian perspective. Saarbrücken, Germany: LAP Lambert.

Statistics South Africa. (2015). Statistical Release P0211.4.4, National and provincial labour market: Long term unemployment (Q3:2008 - Q3:2014). Pretoria: Government Printer.

The National Planning Commission. (2012). National Development Plan (NDP) - 2030. Pretoria: Government Printer.

Thwala, W. D. (2008). Employment creation through public works programmes and projects in South Africa. Acta Commercii, 1, 103-112.

Vidovic, A. B. (2014). Role of the state in the development of entrepreneurship. Socioeconomica, 3(6), 269-276.

WEF (World Economic Forum). (2007). Global Education Initiative. Davos.

WEF (World Economic Forum). (2011). Final report on the entrepreneurship education work stream. Global Education Initiative. Switzerland.

World Bank. (2001). Poverty manual. Washington: World Bank Institute. 